2015 Global Fashion Management Conference at Florence Proceedings: 555-561 (June 2015) http://dx.doi.org/10.15444/GFMC2015.04.06.01

\title{
THE EFFECTS OF BRAND LOYALTY ON THE EMOTIONAL REACTIONS TO A LUXURY BRAND CRISIS: THE MONCLER CASE
}

\author{
Giacomo Gistri, University of Macerata, Italy ${ }^{1)}$ \\ Stefano Pace, Kedge Business School, France \\ Matteo Corciolani, University of Pisa, Italy
}

\begin{abstract}
An empirical research on the Moncler case shows that brand loyalty moderates the consumer reactions to brand crises. While highly loyal consumers express sympathy toward the company, which predicts positive effects on brand attitude and purchase intention, lowly loyal consumers express anger, which predicts negative effects on the dependent variables.
\end{abstract}

Keywords: empirical research, brand loyalty, purchase intention, negative effect, luxury brand

\section{INTRODUCTION AND THEORETICAL BACKGROUND}

Most of the extant literature on brand crisis focuses on two assumptions. First, brand crises are direct and simple. In the traditional scheme of brand crises studied in the literature, a single critical event occurs and the facts are clear. Researchers are usually interested in how the responsibility of the crisis is attributed to the organization and in the effectiveness of the crisis response strategies (Coombs, 2007; Coombs and Holladay, 2008). For instance, a crisis that has been studied is that of the shipwreck of the Costa Concordia. The event was clear (a cruise ship capsized) and the attribution of responsibility was almost unquestioned by the observers (the crisis was due to some mistakes by the organization and/or the captain; Grappi and Romani, 2015). Second, the exposure to the critical event automatically activates a coherent emotional reaction (anger or sympathy) by the stakeholders towards the company, affecting their response towards the crisis and the brand (Claeys and Cauberghe, 2014; Grappi and Romani, 2015; Grappi, Romani, and Bagozzi, 2013).

The first assumption diminishes the complexity of some crises and the interceptive role played by stakeholders. Crises may be multifaceted and may touch different aspects of the company's operations. For instance, the bankruptcy of certain financial service firms at the beginning of the current economic crunch represents a complex crisis. No single event encapsulates the complexity of the crisis and different aspects are contextually present: management misconduct, anomalous market conditions, and insufficient regulations. We cannot expect that, when facing complex crises, a stakeholder would have simple reactions. A stakeholder elaborates the nuances of the crisis and, on the base of that assessment, responds to the crisis in terms of brand attitude and behaviors. As to

1) giacomo.gistri@unimc.it 
the second assumption, the causal link between crisis and emotional arousals seems too direct and it would discard the cognitive appraisal of the crisis by the stakeholder, as indicated in the previous point. A stakeholder's position towards the brand - rather than the simple exposure to a crisis - determines her interpretation of the crisis. The emotion stems from that interpretation. In particular, brand loyalty plays a major role in driving the interpretation and the consequent emotion felt by the customer. Brand loyalty is not only a brand-customer relationship; it may drive elaborate behaviors. For instance, by confirming their loyalty to some brands, dispersed networks of families may reassert their family bonding (Epp, Schau, and Price, 2014). This suggests that loyalty is not only a consequence of brand ability to retain its customers, but also a cognitive position thought which customers perceive and frame life events.

The brand loyalty activates different emotions towards the crisis (namely, anger or sympathy) and those emotions have an impact on attitude towards the company and purchase intention. We focus on anger and sympathy because they are the main emotions raised by the perception of responsibility (Weiner, 1995, cit. in Grappi and Romani, 2015).

Customers with low brand loyalty do not have enough interest and expertise in the brand struck by a complex crisis. Therefore, they would not engage in a deep assessment of the crisis. Low loyalty customers would interpret the crisis at its "face value", i.e. they would focus on the most serious fact of the crisis, determine its most evident responsible, and react instinctively with anger. A low loyal customer would not frame the crisis as a damage to herself, but she would express a righteous anger, that stems from the awareness that some harm is done to someone else (Romani, Grappi, and Bagozzi, 2013). Anger then affects the attitude towards the company and purchase intention (Grappi and Romani, 2015).

On the contrary, customers with high brand loyalty would interpret the crisis in a more complex manner, looking at all its facets and considering the contextual factors of the crisis. A high loyal customer would put the company's responsibility within a wider framework, rather than framing the company as the only cause of the crisis. In addition, brand trust and brand affect are determinants of brand loyalty (Chaudhuri and Holbrook, 2001). Those two attitudes would lead the customer to condone the perceived company's wrongdoing. Finally, the crisis is also a threat to the customer identity and, therefore, the subject would defend herself by expressing a positive emotion of support for the company, which would amount to a support for herself as loyal customer of that brand. Overall, a high loyalty customer would express sympathy towards the company, and increase her attitude towards the company and purchase intention.

These effects are particularly relevant for luxury brands. Their exclusivity may exacerbate negative emotions by non-customers. On the other hand, the same exclusivity would lead loyal customers to feel part of a selected group of consumers and thus express support and sympathy for the brand against the criticismof "outsiders".

We formalize the above reflections in the following hypotheses: 
Hla: For low loyalty customers, a crisis activates anger, which worsens the customer attitude toward the corporate.

H1b: For low loyalty customers, a crisis activates anger, which decreases the customer purchase intention.

H2a: For high loyalty customers, a crisis activates sympathy, which improves the customer attitude toward the corporate.

H2b: For high loyalty customers, a crisis activates sympathy, which increases the customer purchase intention.

\section{EMPIRICAL STUDY}

\section{The Moncler Crisis}

Moncler is a luxury apparel manufacturer known for its sportswear and quilted jackets. On 2 November 2014, a crisis struck the brand. The Italian television newsmagazine "Report" released a journalistic inquiry on the illegal practice of live-plucking on live geese in certain regions of East Europe. The news program linked this practice to the manufacturing of the Moncler down jackets. The inquiry showed also the outsourcing of some phases of the manufacturing and the very high margins of the luxury industry, with production costs in the order of $€ 30-50$ and retail prices in the range of $€ 1.500-2.000$ for a jacket or dress. The inquiry stemmed a public debate and there was an uproar against luxury companies and the brand Moncler in particular. Immediately after the broadcast, Moncler issued a press release where it clarified that the suppliers of feathers comply with the principles of the European Down and Feather Association and defended against the accusation against the other business practices cited in the news report.

The crisis endured by the brand Moncler is complex. The main accusations against Moncler regards the treatment of geese and it can be classified in the preventable type of crisis (Coombs, 2007), which is the most serious type of crisis in terms of damage for the brand reputation. In addition to that, the accusation referred the entire luxury sector, its prices, which are perceived as unjustified, and the practice of outsourcing manufacturing in a moment of economic downturn, which would instead call for national interments.

\section{Methodology}

Our investigation focuses on the recent brand crisis experienced by the company Moncler. To collect data, we created a questionnaire and we ran a web survey through Survey Monkey. The questionnaire includes existing scales already tested and available in literature and in the last section, some socio-demographic items were also included.

\section{[Insert Table 1 about here]}

The sample is composed by 115 real consumers ( 34 men, 81 women; $\mathrm{M}_{\mathrm{age}}=28.35$ years).

\section{RESULTS}

To investigate the impact of the crisis on consumer responses, we considered two dependent variables: the attitude toward the company and the purchase intention. As we 
imagine that different effects on consumers may be based on different levels of brand loyalty, we did a median-split of the sample and divided it in two groups: highly vs. lowly loyal consumers.

\section{[Insert Table 2 about here]}

As indicated in table 2, in case of low loyalty, the attitude toward the corporate decreases because of the emotion of anger felt by consumers after the crisis. Instead, in case of high loyalty, anger does not have a significant effect. The opposite happens for the emotion of sympathy: while, in case of high loyalty, it increases the attitude toward the company, in case of low loyalty, it does not significantly affect the dependent variable. Therefore, both hypotheses $1 \mathrm{a}$ and $2 \mathrm{a}$ are verified.

\section{[Insert Table 3 about here]}

As indicated in table 3, in case of low loyalty, the purchase intention decreases because of the emotion of anger, which is felt by consumers after the crisis. In case of high loyalty, however, anger does not have a significant effect on the dependent variable. The opposite happens for the emotion of sympathy: it increases the purchase intention in case of high loyalty, while it does not significantly affect the dependent variable in case of low loyalty. This provides support for both hypotheses $1 b$ and $2 b$.

\section{DISCUSSION AND IMPLICATIONS}

In this article, we obtain two important insights on the consumer reactions to brand crises. First, we show that, when a crisis is complex and involves more than one issue (e.g. treatment of geese, outsourcing manufacturing, etc.), consumer responses tend to become more complex and change from subject to subject. Second, we illustrate that, when facing complex crises, consumes have an important interpretative role, which precedes the consequent emotional reactions. In particular, we demonstrate that, depending on their level of brand loyalty (Epp et al., 2014), individuals who are exposed to a brand crisis may feel different emotions toward it (e.g. Grappi and Romani, 2015). That is, highly loyal consumers tend to perceive a complex crisis as a broader fact (e.g. what happens to Moncler is common in the context of luxury brands) and to express sympathy toward the company. Conversely, lowly loyal consumers may focus on a more specific aspect of the crisis (e.g. treatment of geese) and on its direct cause (i.e. Moncler), which produces a reaction of anger.

The most important implication of this study is that of showing the strategic importance of the interaction between company and customer in case of brand crises. Indeed, more loyal customers may represent a key instrument of brand defense in case of crisis. Their positive brand attitude, which tends to live through the crisis, may develop an important horizontal communication, which effectively integrates the company's vertical communication. Importantly, owing to the increasingly relevant role of social media in the communication among individuals, this horizontal form of communication tends to be even more strategic for the company (see Pace, Balboni, and Gistri, 2014). Future research may examine more in depth the moderating role of brand loyalty. For example, 
the cognitive, emotional, and behavioral dimensions of this construct might be analyzed to verify whether they may predict different responses to brand crises.

\section{REFERENCES}

Burton, S., Garretson, J.A., \& Velliquette, A.M. (1999). Implications of accurate usage of nutrition facts panel information for food product evaluations and purchase intentions. Journal of Academy of Marketing Science, 27(4), 470-480.

Chaudhuri, A., \& Holbrook, M.B. (2001). The chain of effects from brand trust and brand affect to brand performance: The role of brand loyalty. Journal of Marketing, 65(2), 81-93.

Claeys, A.S., \& Cauberghe, V. (2014). What makes crisis response strategies work? The impact of crisis involvement and message framing. Journal of Business Research, 67(2), 182-189.

Coombs, T.W. (2007). Protecting organization reputations during a crisis: The development and application of situational crisis communication theory. Corporate Reputation Review, 10(3), 163-176.

Coombs, T.W., \& Holladay, S.J. (2008). Comparing apology to equivalent crisis response strategies: Clarifying apology's role and value in crisis communication. Public Relations Review, 34(3), 252-257.

Epp, A.M., Schau, H.J., \& Price, L.L. (2014). The role of brands and mediating technologies in assembling long-distance family practices. Journal of Marketing, $78(3), 81-101$.

Gelbrich, K. (2011). I have paid less than you! The emotional and behavioral consequences of advantaged price inequality. Journal of Retailing, 87(2), 207-224.

Grappi S., \& Romani, S. (2015). Company post-crisis communication strategies and the psychological mechanism underlying consumer reactions. Journal of Public Relations Research, 27(1), 22-45.

Grappi S., Romani, S., \& Bagozzi, R.P. (2013). Consumer response to corporate irresponsible behavior: Moral emotions and virtues. Journal of Business Research, 66(10), 1814-1821.

Harris, L.C., \& Goode, M.H. (2004). The four levels of loyalty and the pivotal role of trust: a study of online service dynamics. Journal of Retailing, 80(2), 139-158.

Malär, L., Krohmer, H., Wayne, D.H., \& Nyffenegger, B. (2011). Emotional brand attachment and brand personality: The relative importance of the actual and the ideal self. Journal of Marketing, 75(4), 35-52.

Pace, S., Balboni, B., \& Gistri, G. (2014). The effects of social media on brand attitude and WOM during a brand crisis: Evidences from the Barilla case. Journal of Marketing Communications, doi:10.1080/13527266.2014.966478.

Pope, N.K., Voges, K.E., \& Brown, M.R. (2004). The effect of provocation in the form of mild erotica on attitude to the ad and corporate image. Journal of Advertising, 33(1), 69-82. 
Richins, M.L. (1983). Analysis of consumer interaction styles in the marketplace. Journal of Consumer Research, 10(6), 73-82.

Romani, S., Grappi, S., \& Bagozzi, R.P. (2013). My anger is your gain, my contempt your loss: Explaining consumer responses to corporate wrongdoing. Psychology and Marketing, 30(12), 1029-1042.

Small, D.A., \& Verrochi, N.M. (2009). The face of need: Facial emotion expression on charity advertisements. Journal of Marketing Research, 46(6), 777-787.

Weiner, B. (1995). Judgments of responsibility. New York, NY: Guilford.

\section{TABLES}

Table 1. Scales

\begin{tabular}{|c|c|c|}
\hline Scale & Description & $\begin{array}{l}\text { Cronbach } \\
\text { alpha }\end{array}$ \\
\hline $\begin{array}{l}\text { Attitude toward the corporate (Pope, } \\
\text { Voges, and Brown, 2004) }\end{array}$ & $\begin{array}{l}5 \text { items, } 7 \text { point semantic } \\
\text { differential }\end{array}$ & $(\alpha=0,79)$ \\
\hline $\begin{array}{l}\text { Purchase intention (Burton, Garretson, } \\
\text { and Velliquette, 1999) }\end{array}$ & 3 items, 7 points Likert & $(\alpha=0,93)$ \\
\hline Brand loyalty (Harris and Goode, 2004) & 4 items, 7 points Likert & $(\alpha=0,71)$ \\
\hline $\begin{array}{l}\text { Attitude toward business in general } \\
\text { (Richins, 1983) }\end{array}$ & 6 items, 7 points Likert & $(\alpha=0,78)$ \\
\hline $\begin{array}{l}\text { Personal crisis relevance (Malär, } \\
\text { Krohmer, Wayne, and Nyffenegger, } \\
\text { 2011) }\end{array}$ & 5 items, 5 points Likert & $(\alpha=0,92)$ \\
\hline Anger (Gelbrich, 2011) & 3 items, 7 points Likert & $(\alpha=0,83)$ \\
\hline Sympathy (Small and Verrochi, 2009) & $\begin{array}{l}4 \text { seven point uni-polar } \\
\text { items }\end{array}$ & $(\alpha=0,85)$ \\
\hline
\end{tabular}

Table 2. Multiple regression with the attitude toward the corporate as dependent variable

\begin{tabular}{|c|c|c|c|c|c|}
\hline \multirow[t]{2}{*}{ Model } & \multicolumn{2}{|c|}{$\begin{array}{l}\text { Unstandardized } \\
\text { Coefficients }\end{array}$} & \multirow{2}{*}{\begin{tabular}{|c|}
$\begin{array}{c}\text { Standardized } \\
\text { Coefficients }\end{array}$ \\
Beta \\
\end{tabular}} & \multirow[t]{2}{*}{$\mathbf{t}$} & \multirow[t]{2}{*}{ Sig. } \\
\hline & $\mathbf{B}$ & Std. Error & & & \\
\hline \multicolumn{6}{|c|}{ Low loyalty } \\
\hline (Constant) & 3,672 & 1,434 & & 2,561 &, 014 \\
\hline $\begin{array}{l}\text { Attitude toward business } \\
\text { in general }\end{array}$ & ,489 & , 194 & ,268 & 2,524 &, 015 \\
\hline Personal crisis relevance &, 017 & ,118 &, 016 & 141 & ,889 \\
\hline Sex &,- 742 & 297 &,- 265 & $-2,498$ & ,016 \\
\hline Age &, 034 & 013 & 269 & 2,646 & ,011 \\
\hline Anger &,- 422 & 136 &,- 403 & $-3,110$ &, 003 \\
\hline Sympathy &, 113 & 185 & ,083 & 610 &, 545 \\
\hline \multicolumn{6}{|c|}{$\mathrm{R}^{2}=0,57-\mathrm{R}^{2} \mathrm{Adj}=0,51$} \\
\hline \multicolumn{6}{|c|}{ High Loyalty } \\
\hline (Constant) & 3,104 & 1,301 & & 2,385 & ,021 \\
\hline
\end{tabular}




\begin{tabular}{|l|c|c|c|c|c|} 
Attitude toward business &,- 013 &, 222 &,- 008 &,- 057 &, 955 \\
in general &, 062 &, 140 &, 059 &, 440 &, 661 \\
Personal crisis relevance &,- 433 &, 321 &,- 167 & $-1,348$ &, 183 \\
Sex &, 016 &, 015 &, 138 & 1,038 &, 304 \\
Age &,- 085 &, 121 &,- 104 &,- 702 &, 486 \\
Anger &, 496 &, 157 &, 432 & 3,153 &, 003 \\
Sympathy & $\mathrm{R}^{2}=0,22-\mathrm{R}^{2} \mathrm{Adj}=0,13$ \\
\hline \multicolumn{4}{|l}{}
\end{tabular}

Table 3. Multiple regression with the purchase intention as dependent variable

\begin{tabular}{|c|c|c|c|c|c|}
\hline \multirow[t]{2}{*}{ Model } & \multicolumn{2}{|c|}{$\begin{array}{l}\text { Unstandardized } \\
\text { Coefficients }\end{array}$} & \multirow{2}{*}{\begin{tabular}{|c|}
$\begin{array}{c}\text { Standardiz } \\
\text { ed } \\
\text { Coefficients }\end{array}$ \\
Beta \\
\end{tabular}} & \multirow[t]{2}{*}{$\mathbf{t}$} & \multirow[t]{2}{*}{ Sig. } \\
\hline & $\overline{\mathbf{B}}$ & Std. Error & & & \\
\hline \multicolumn{6}{|c|}{ Low Loyalty } \\
\hline (Constant) & 7,119 & 1,926 & & 3,697 &, 001 \\
\hline $\begin{array}{l}\text { Attitude toward business in } \\
\text { general }\end{array}$ &, 164 & ,260 & ,077 & 632 &, 530 \\
\hline Personal crisis relevance & ,318 & ,158 & ,255 & 2,008 & 051 \\
\hline Sex & $-1,340$ & ,399 &,- 409 & $-3,361$ & ,002 \\
\hline Age &,- 001 & ,017 &,- 008 &,- 072 & ,943 \\
\hline Anger &,- 660 & ,182 &,- 536 & $-3,618$ & 001 \\
\hline Sympathy &,- 196 & 249 &,- 122 &,- 786 & ,436 \\
\hline \multicolumn{6}{|c|}{$\mathrm{R}^{2}=0,44-\mathrm{R}^{2} \mathrm{Adj}=0,36$} \\
\hline \multicolumn{6}{|c|}{ High Loyalty } \\
\hline (Constant) & 3,820 & 1,820 & & 2,099 &, 041 \\
\hline $\begin{array}{l}\text { Attitude toward business in } \\
\text { general }\end{array}$ &,- 424 & ,310 &,- 185 & $-1,367$ & ,177 \\
\hline Personal crisis relevance & ,445 & 196 & 296 & 2,270 & ,027 \\
\hline Sex &,- 214 & 449 &,- 058 &,- 478 & 635 \\
\hline Age &,- 014 & 021 &,- 086 &,- 663 &, 510 \\
\hline Anger &,- 253 & , 170 &,- 216 & $-1,493$ & 141 \\
\hline Sympathy & ,638 & ,220 & ,388 & 2,904 & ,005 \\
\hline
\end{tabular}

